\title{
Article \\ The Right to Water, Law and Municipal Practice: Case Studies from India
}

\author{
Arkaja Singh $\mathbb{C}$
}

check for

updates

Citation: Singh, A. The Right to Water, Law and Municipal Practice: Case Studies from India. Water 2022, 14, 73. https://doi.org/10.3390/ w14010073

Academic Editor: Guy Howard

Received: 17 November 2021

Accepted: 22 December 2021

Published: 1 January 2022

Publisher's Note: MDPI stays neutral with regard to jurisdictional claims in published maps and institutional affiliations.

Copyright: (C) 2022 by the author. Licensee MDPI, Basel, Switzerland. This article is an open access article distributed under the terms and conditions of the Creative Commons Attribution (CC BY) license (https:// creativecommons.org/licenses/by/ $4.0 /)$.
Centre for Policy Research, State Capacity Initiative, New Delhi 110021, India; arkaja@cprindia.org or arkaja@gmail.com

\begin{abstract}
Recognition of the right to water in Indian courts has had little impact on the ground. This paper explores the seeming disjuncture between what happens in the court and the everyday reality of living with a less-than-perfect claim on city water services in India's urban slums. The paper seeks to understand and contextualise a court ruling which looks like it declares a right to water for people in urban slums, but in effect gives them little beyond what they already had. The paper also looks at the 'everyday reality' of municipal administration and the provision of drinking water in slums through in-house connections and community taps. In both case studies, the author looks to understand how the practice relates to frameworks of law and policy that shape the rationality and scope of action of the actors concerned, both judges and municipal officials. She found that the issue of land was the main stumbling block in both places, but it was conceptualized a little differently in each situation. These case studies underscore the critical importance of making the local interface between poor people and the state more empowering in order for rights to become local and meaningful.
\end{abstract}

Keywords: human right to water and sanitation; water access; impact and efficacy of human rights

\section{Introduction}

The courts in India have declared the right to water to be a constitutionally recognized right; however, this right has not (except in very rare exceptions) been translated into legislation or state policy. It is very seldom demanded by social movements, except sometimes in rights litigation. It is almost never brought up in the context of drinking water alone but seems instead to be appended to other issues such as environmental pollution, displacement, slum evictions and battles over natural resources. Moreover, in urban contexts, the groups that are underserved and excluded from mainline drinking water services seldom mobilise to invoke this right. Instead, the excluded might make a pragmatic compromise, in which they settle for a less-than-perfect claim of human entitlement for some 'special regimes' that are designed for their unequal status.

In this paper, I will explore the disjuncture between the regime of rights, and the maze of local administration. For this, I looked at two arenas of engagement: one in which the 'right to water' is well recognized, and another in which access is negotiated through a special regime built of law and administrative practice in which there is no explicit recognition of the right to water. Instead, the logic of poverty alleviation and some diffuse notion of human entitlement provide rationality for this special regime which is built on everyday interactions between the poor and the state.

These two arenas show us how the right to water is inextricably tied up with the issue of land. It remains entangled in land, in not entirely dissimilar ways, even as we move between two alternative spheres of rationality: of socio-economic rights jurisprudence and of municipal administration, respectively. Both of these spheres of rationality have their uses and their limitations, and there are usually very persuasive reasons, local and legal, why people might choose to approach the court in some cases and not in others. 
Putting together the two cases provides some useful insight into how the discourse of socio-economic rights runs aground in real life situations of deprivation.

My case studies relate to people in urban slums who face some specific types of exclusion from the mainstream urban water supply provisioning. These difficulties seem to be linked directly to their being in slums, and to their legal status in relation to the land that they occupy. The issue of land allows them a very limited type of right to water in the eyes of the court they approached to make a claim for their right to water. The problem of land and the status of excluded communities in relation to land is the main issue even in the arena of municipal administration; however, a different framework of rules allows for the possibility of some kinds of legitimacy, and with fewer attendant risks.

The issue of land in relation to slums and water supply is not simply one of squatting or illegal capture of land, although there may be elements of that in many slums. Slums tend to contravene some aspect of the writ of the state with respect to property and planning control, but they could equally have some recognition from the state of their tenure claims and planning status. Concomitantly, the drinking water problem in slums also has some specific dimensions.

The difference in access to piped water supply (as opposed to that from local borewells or tankers) is not immense: it is estimated that 51 percent of slum households rely on piped water as their main source of water, as compared to 57 percent in non-slum areas [1]. However, slum households are far more likely than non-slum households to have community taps or shared water connections as their source of piped water, and to have to rely on shared borewells and tankers where piped water is not available. In comparison, the off-network non-slum areas are more likely to have in-house water connections, or to have their own borewells and private arrangements. Slum households are also more likely to access supplies that are less reliable, available for less time and at lower pressure than in non-slum households [2-4].

The rules of water service provision are seldom the same for slum and non-slum settlements. This differential set of administrative procedures and protocols for water supply in slums accounts for the land status of slums. In my first case, a new set of rules directed municipalities to cut off previously legal connections from a specified category of slums. In my second case, I explore a 'special regime' that provides them water, but of a lower grade than what is supplied in non-slum areas.

In both cases, it is pertinent that people in slums have a background threat of evictions, disconnections and shut-downs because of how they are located in terms of the rules of property titling, building plan approval, trade licensing and myriad other forms of state control. People in slumsare mindful of these background threats in their negotiations with the state. To 'live in the face of the tiger' [5] requires careful collective strategizing on the part of the slum residents.

The issue of drinking water in slums is also one of engineering failures: of plans that overlooked resident populations in the slums or failed to provide for them, of inadequate maintenance or of the practice of diverting water elsewhere when there is scarcity in the system. These engineering failures could be considered 'hydraulic' water problems, as opposed to 'legal' water problems [6]. But hydraulic problems might themselves originate in the unrecognized planning status of the slum, and how this is understood in the domain of municipal engineering.

Another dimension of the water problem in slums is the apparent need for slum residents to politically organize themselves in order to get the municipality to act. There is quite a lot of ambiguity in the rules and in how (and perhaps to what extent) these rules can be applied to idiosyncratic municipal water supply lines, which leaves room for local inconsistencies. Settlements that are quite securely placed in legal terms might also struggle with inadequate access to drinking water, whereas places that have very little by way of legal status might be able to secure some form of municipal drinking water. The extent to which residents can organize themselves and make connections with political networks seems extremely relevant to how much of the municipal services and state welfare 
are available to them $[2,7,8]$. However, this does not make the rules irrelevant. Rather, the formal rules of inclusion and access provide the terrain that is navigated through collective positioning.

\section{Materials and Methods}

The material relating to the two situations described in the case studies were drawn from a variety of sources. In the first case study, I focused on one court ruling and looked at the related legal rules that constituted the 'cause of action' as well as what emerged as an outcome of the ruling. I looked at related social science literature and news articles to provide context to the situation. I also referred to selected pieces of policy literature, discussions and opinion pieces where relevant for key themes of interest in the case study.

The objective of my second case study was to build an understanding of the situation. This situation is specific to place and time in some ways, although its key features could be applied more broadly to drinking water issues in India's urban slums. I have used the case of Madhya Pradesh cities. My case deals with local law, institutional arrangements and administrative practice. Much of this relates to the municipality; however, it is determined at the state level. There are some city-specific variations and size-category variations. Of these, the size category variations seemed to be specific to my case study, and, therefore, I have restricted my focus to the larger cities in the state with a population of more than one million.

For the second case, I have drawn on my consultant work. I worked from 2006-2009 in a poverty alleviation programme funded by Britain's international aid agency (then known as the Department for International Development, or DFID) in the state of Madhya Pradesh where I helped coordinate the implementation of water supply and other services improvements in urban slums in the state. In this time, I worked closely with a team of municipal officials and consultant colleagues to plan and implement a scheme to deliver household water connections to the poorest and most infrastructure-deprived areas of the cities in which the programme was applied. My own location at the time in Madhya Pradesh provided a vantage point from which to understand the local interface of the state with the cities' poorest residents. I remained engaged with further developments in the state's urban policies through subsequent donor-funded assignments. I have drawn on my own notes and subsequent discussions I had with municipal and urban administration staff in the state of Madhya Pradesh. The people I have spoken to are, however, not named, as most of our conversations were conducted with this understanding. I have cross-checked what I learned from my discussions by referring to alternative sources, application forms, website links and news reports.

From the time I have been keeping up with this case, there have been several programmatic changes in Indian urban policy. Many of these have come in the form of central government-funded schemes for the development of public infrastructure and housing, with related policy goals and scheme conditions. Programme targets under these schemes might have the effect of speeding up budgetary allocations, tenure grants and approvals from time to time. Election cycles in state and municipal elections might also have similar effects. However, it is my understanding that they have not significantly altered the framework of rules and rationality that I have dealt with in my case study. For this reason, I have chosen to keep them out of the present narrative.

\section{The Struggle for Municipal Drinking Water, in Courts and in Municipal Administration}

\subsection{Judicial Recognition of the Right to Water}

My first case is of Pani Haq Samiti [9], which is perhaps the only Indian court case in which the principal point is of the constitutional right to water in urban slums. In 2012, the petitioners - a Mumbai NGO_challenged a government rule that barred the Mumbai Municipal Corporation from providing water to houses in slums which could not show evidence of having been in existence from before a stipulated "cut off date". By state law applicable to slums in Mumbai, slum residents who showed evidence of 
their presence before 1 January 1995 were eligible for the issue of a "photo pass", and were considered "protected occupiers", by which they were protected from eviction except by way of a relocation and rehabilitation scheme formulated by the government. (In the Maharashtra Slum Areas (Improvement and Clearance) Act, 1971, this provision was added by amendment in 2002). By this measure, 1 January 1995 came to be considered the cut-off date, which was subsequently extended to 1 January 2000.

This policy created a category of slum housing which was ineligible for rehabilitation, and came to be referred to as "illegal structures". Subsequently, a government circular issued on 4 March 1996 directed local authorities to ensure that water supply is not released to any unauthorised constructions. Rules formulated by the municipal corporation of Mumbai also provided for water supply only to protected occupiers. This implied that the corporation had to shut off supply to "illegal structures", even those that previously had entirely legitimate water connections to the city water supply network.

This rule was successfully challenged by Pani Haq Samiti on the ground that it was violative of Article 21, or the constitutional right to life. In their decree, the judges relied on previous judgements for an expansive interpretation of the right to life as including the right to food, water, shelter, decent environment, livelihoods, medical care, facilities for reading, etc. The petitioners had also referred to the international human right to water and the International Covenant on Economic, Social and Cultural Rights, which this court (relying on previous judgements) used to support its expansion of Article 21.

However, the court clarified that the right to shelter guaranteed under Article 21 did not extend to protecting possession of illegal and unauthorised housing. Therefore, even though the state or the municipal corporation could not deny water supply to a person on the ground that he is residing in an illegal structure, the person had no right to retain the illegally constructed structure. Elaborating on this, the judges said that they were sympathetic to the fact that there was a lack of affordable housing in the city that was resulting in the proliferation of illegal housing, but, nonetheless, they observed that it was the duty of the municipal corporation to demolish illegal housing. In their final directions in this case, they reiterated this, and gave specific directions to the municipality to report back to the court about actions taken towards this end.

The court also held that people living in illegal slums could be made to pay higher rates for water supply than others for the reason that "a citizen who stays in an illegal structure on in illegal slums cannot claim [the] right to get water supply on par with water supply made available to a law abiding citizen who has either constructed his house after obtaining a permission or who is occupying a residential premises which is lawfully constructed and which is permitted to be occupied". It held that it was for the municipal authority to decide in what manner water could be supplied to illegally constructed slums, and to evolve a policy for it, which need not be in the form of piped water to individual dwellings. This policy could include a provision of payment of water charges, which could be at a higher rate than the rate that is charged for water supply to authorised constructions.

Apparently (as noted in the court's decree), the petitioners had suggested that the municipality could supply water through water booths and prepaid cards, which the court held was an option that could be considered. Further, the court held that its ruling in this case did not apply if there was a specific prohibition on supply of water in any particular area by another ruling of the court. The municipal corporation was directed to formulate a policy for water supply to illegal slums on these lines, and to report back with an affidavit of compliance within 10 weeks of the order.

Subsequent news reports suggest that a 'Water for All' policy was finally approved in 2016 (almost two years after the date of the High Court order), which provided for household water connections to the illegal slums. In terms of this policy, water charges in illegal slums were higher than what was applicable for slums from before the cut-off date [10]. I could not find a copy of the actual policy, however, its existence was confirmed in my phone conversation with Sitaram Shehlar, the convenor of the Pani Haq Samiti NGO on 5 February 2020. This policy required that the municipal corporation obtain clearances 
from several other agencies in order for water connections to be provided in many of the locations and for households that were previously barred. In practice, this means that slum residents themselves have to organise and lobby for all the clearances from other agencies, and whether or not the approval is at all forthcoming might depend on the status and classification of the land on which the slum is located.

Confusingly, the municipal website makes no mention of this policy but instead states that: 'It is our commitment to provide access to water to all the citizens of Mumbai and we recognize that a large part of our community is living in the informal settlements. Water services are provided to these informal settlements in the form of a common connection in General Washing Place (GWP) for a group of minimum 5 households. The citizens in slums having proof of existence prior to 01.01.2000 are eligible for water connection as per present policy.' [11]. This is, in effect, the legal position from before the Pani Haq Samiti ruling, and suggests that there has been little impact of what the court said on the municipal corporation. By recent estimates, 2 million people are denied legal water access in the city of Mumbai and live amidst severe water insecurity. Moreover, 70 percent of these people are still being denied water on account of the original "cut-off date" of 1 January 1995 [12].

On the other hand, the Pani Haq Samiti court did not make any directions about establishing a regular and reliable service, it did not stipulate quantity or quality and it did not seek a commitment as to when it would be implemented. On costs, the court seemed to think that a higher tariff, and even a tariff with a punitive element, was acceptable. Moreover, the fact that the government policy made as a result of this judgment imposes very difficult conditions for residents of illegal slums is not a violation of the principles established in this case.

I understand that there were no slum evictions that could be linked to the court's directions to demolish 'illegal housing' in this case, in spite of what the court said about it, which is perhaps a reflection of the agility with which local authorities can negotiate around court diktat. However, leaving aside for a moment the local authorities' adroit management of the demolitions issue, it would be useful to reflect on the reason why the right to water court's formulation of the right to water is so measly in that it does not even entitle people to a basic standard of regular and reliable provision? For this we could look at the background of the government policy that was challenged in this case. The particularities of this policy are local, but this background is useful in thinking about why the right to water fails those for whom it is most needed.

The Mumbai policy that linked eligibility for water connections to a stipulated 'cut-off date' was closely connected with slum development policy (and the 'slum development scheme') of 1995 that was notified under the Maharashtra Slum Areas (Improvement and Clearance) Act, 1971. The 'cut-off date' referred to in the Pani Haq Samiti case was really the cut-off date for eligibility under the slum policy. By this policy, real estate developers could construct slum redevelopments and new housing projects for people in slums. In exchange, a part of the land on which the slum was located was to be freed up by reorganising the slum into multi-storey housing, which the developer could use as commercial real estate. In addition, developers were given transferable FAR (floor-area ratio rights) or 'transferable development rights,' which could be used elsewhere or sold in the market to other construction projects.

Mumbai's slum redevelopment policy suited both politicians and technocrats, as it seemed to provide a solution to the city's problem of unaffordable real estate and constrained supply of housing. Moreover, this solution seemed to consist only of policy and financing innovations, and was thought not to impose any financial burden on the government, while giving slum households a highly subsidised house with secure tenure. At the same time, it could release large amounts of land for real estate development. All in all, a win-win in the recently liberalised Indian economy of the 1990s, as evidenced by the fact that the policy was smoothly incorporated into the corporate vision of Mumbai and energetically supported by international aid agencies [13,14]. 
However, the dark side of this policy was that it needed a cut-off date for its legitimacy [6]. Local critics feared it would attract free-riders and lead to the creation of new slums, and Indian bureaucrats have a marked preference for finite solutions and one-time handouts for people in slums. The cut-off date and the water disconnections also perhaps helped the political sponsors of this policy build nativist support by differentiating between earlier settlers (presumably from the same state) and later arrivals who came from further away (the northern states of India, and possibly Bangladesh) [4,8]. The linking of municipal water supply to the cut-off date was, in this context, an additional step to reassure critics that conditions in the non-eligible slums were not being made too attractive. Its main purpose seems to be to endorse the logic that slums from before the cut-off date were entitled to remain and be rehabilitated, whereas the ones that came after were illegal and should be removed.

On the other hand, it is unlikely that the policy linking water supply to the cut-off date is the result of a water privatisation agenda, even though it happened at the time when privatisation of Mumbai's water supply was on the table. The idea of reorganising water supply services in Mumbai along commercial principles was in circulation in government and policy circles in the period of the 1990s and early 2000s. At this time, the World Bank strongly promoted the idea of greater cost recovery in water services through metering and tariff increases [15]. However, 'in the end the privatisation storm blew over,' and it is likely that it was never a real possibility given the many complex and knotty problems that any real restructuring effort would have had to resolve [6].

However, the main reason why I think the two are not connected is that the policy to link water services to the cut-off date brought about the illegalisation of large numbers of water connections and supply points that were formerly legal. This drove a large part of Mumbai's water operations underground and took it off the balance sheets of the municipal corporation. Had it been legal, it would have been easier to account for, and would have generated some amount of water supply revenue, even if it was not profitable. In her study of water in Mumbai which covers this period, Bjorkman also found no direct connection between the World Bank's policy advocacy work and the water disconnection policy, although she found that the government's water supply scheme which was inspired by this advocacy work contained a proposal for a distinct type of pre-paid water connection in the post cut-off date slums [6].

Coming back to Pani Haq Samiti, the three prominent features in the case-punitive tariff, limited services and making this subject to land approvals-are all linked to the logic of the cut-off date, and the idea that post-cut-off date households have a lower claim on the system. This, I believe, is just one instance of many across India's drinking water regimes, in which elite ways of thinking about land as property override the legal conception of the right to water.

\subsection{Municipal Drinking Water in Administrative Rule and Practice}

In many discussions about the issue of drinking water in the slum areas in Madhya Pradesh cities that I have had in the period of 2006-2018, I learned that the quality of drinking water provision is indeed closely tied to the issue of land, but that this connection is a bit more complicated than it would appear to be in Pani Haq Samiti.

Access to drinking water in slums seems to be of poorer water quality, of less quantity and far less secure than that of people in non-slum areas, which has health, economic and quality of life implications for them. And yet, there is hardly any right to water mobilisation in the courts, or in popular discourse, considering the scale and widespread nature of the problem.

People living in Indian slums might have a slightly better actual legal position in relation to municipal water than in the Pani Haq Samiti judgement. This is because there are other sources of rule, procedure and administrative practice, in which a slum settlement (and a household within a settlement) can be recognised. However, slum residents are in a lower position as compared to the 'law abiding citizens' in non-poor housing colonies 
even in local rule and practice. As in the court, this distinction is built around property and planning regulations.

The administrative rules and practice that I refer to draw on municipal and planning legislation, land revenue codes and the service conditions and service rules that are applicable to people in government employment. Rules and practice also draw on engineering codes, standards and norms, and on administrative circulars and directions that officials receive from higher levels of the government hierarchy. This gives the rules and practice a type of immutable rationality, which can be quite resistant to high-level changes such as in judicial discourse.

On the other hand, the rules and practice belong to the 'street-level bureaucracy' of the municipality, who interact with citizens in the course of the job and have discretion, but cannot do the job according to ideal conceptions of the practice because of the limitations of the work structure [16]. Any spending of government money must be 'sanctioned' or approved, but officials have some room for manoeuvre in deciding which case to put up on the file and how to formulate the case. Moreover, the piped water supply network is not entirely bound by a framework of rules. It is not fully mapped or documented, and is full of ad hoc extensions and modifications, which allow plenty of room for local agency.

In part, this situation is sustained by the fact that water supply revenues do not feature very high in a municipal officials' list of priorities. In fact, they are far less concerned about it than the Pani Haq Samiti judges. Tariffs are low overall, and no Indian city raises enough money from water tariffs to cover the cost of its water supply operations, in spite of several decades of policy pressure to do so. National government schemes and multilateral programmes call for improvements in the accounting and revenue efficiency of water supply operations as a 'reform' condition for funding disbursements; however, these conditions remain widely unfulfilled.

The actions of municipal officials also need to be understood in the context of the fact that the municipality is political, by which I mean that the mayor and the elected council who have considerable power and influence over what the municipality does, are not as invested in administrative rules as career civil servants. The councilors and officials themselves are often local residents of the city, and not so high in social status-and are therefore often easily approached by groups for poor people to intercede on their behalf to resolve water supply issues. There were commonplace instances of municipal councilors and officials being 'encircled' by local residents-sometimes groups of women - when they were out on a site visit, and being held in some sort of friendly custody until they would agree to address some pressing local issue.

It is easy to see how this administrative context facilitates illegal water connections, however, illegal connections can only reach as far as there is municipal drinking water supply. Illegal connections also cannot quite bridge the gap between slums and the rest of the city, which remains stark in spite of whatever marginal additions are brought about through illegal extensions.

\subsection{Within City Disparities}

In the data, drinking water provision in India is categorized as within premises supply (i.e., in-house), and supply from shared community sources. This latter category includes community taps and tankers, and sometimes large plastic storage tanks, fitted with a tap, which are filled intermittently through municipal supply lines or tankers and serve as a type of community tap. Community taps and neighbourhood level supplies could also be arranged through local borewells—some of which are municipal owned-which supply untreated water directly from the borewell. Municipalities also provide a survival essential tanker service in areas where there is not enough piped water supply or community taps.

In the official-speak of Madhya Pradesh municipal officials, community taps are provided in areas where it is not possible to provide regular in-house connections for legal or infrastructural reasons, and community taps are meant to be removed from an area once in-house connections are provided. Community taps are provided free-of-cost 
by the municipality, and mostly only in poor neighbourhoods. New peri-urban gated communities and residential developments that fall outside of existing municipal supply networks are more likely to have private borewells or a private tanker supply.

In the last (albeit not particularly recent) national survey focusing on services deficiencies in slums [1], it was reported that around 80 percent of slum households in the larger cities in Madhya Pradesh (i.e., cities with a population of more than one million) were dependent on community taps for their main source of drinking water, whereas another 20 percent depended on taps shared with neighbours. The number of houses that reported having an exclusive, in-house taps in slums was negligible on the whole. In comparison, in non-slum areas in the same city, 24 percent depended on community taps, 40 percent shared taps or sources of water with their neighbours and 36 percent had exclusive water connections. These community arrangements included both public stand-posts which provide piped water supply and other ground water sources such as wells, tube-wells and boreholes. Moreover, 46 percent of slum households walked more than 200 metres to have access to drinking water.

These numbers suggest that the difference between slum and non-slum areas is not absolute- there is substantial water related difficulty outside of slum areas as well; however, the slum areas look considerably worse. Besides, with more money and space, households without exclusive or municipal water outside of the slums might have a better capacity to cope through alternative means (such as through private borewells, on-site reservoirs and overhead storage tanks). There might have been some improvements in the period since this survey, although I could not find any official reports of transformative change in policy or outcome.

\subsection{The Administrative Framework for Recognising Slums}

While census and survey operations tend to recognize and count slums by what they are in physical terms, in order to be provided with municipal services an informal settlement seems to need some form of administrative recognition. For this, the Madhya Pradesh municipalities use their powers under a slum clearance law [17], which gives the municipality power to remove or undertake improvements in settlements that are 'notified' by it as slums.

By legal definition, a slum is an area that is "a source of danger to the health, safety and convenience of the public of that area or its neighbourhood, by reason of the area having inadequate or no basic amenities, or being insanitary, squalid, overcrowded or otherwise" [17]. This definition does not say anything about whether or not it is a squatter settlement, and whether the residents can claim to 'own' the property they live in. The definition also does not say anything about zoning and building regulations.

In administrative practice and social welfare policy, however, a slum is a conflation of tenurial and zoning irregularities and the fact of its residents being recognized as poor in state welfare programming. Slums are notified in order for them to become eligible for municipal infrastructure and engineering, and in order for them to become sites of welfare and community development programmes of the state. The municipality has a separate department to deal with slums, and a specialized staff of community officers to undertake planning and social development activities in slums.

By these measures, slums can be improved in terms of living conditions and socioeconomic prospects for their residents; however, the tenure and planning irregularities, and the physical constraints of congested housing in unsuitable places, can never be fully overcome. The steps to government recognition, and towards securing claims to land and basic services, have been described as the incremental buildup of tenure security. This 'incremental' approach is widely considered a pragmatic and durable strategy for dealing with urban poverty $[18,19]$. However, it does not lead to a route to the very top. Moreover, the steps require some proactive mobilization of local officialdom and politicians by the community. 
The process of slum notification is one such step. By administrative norm, municipal officials say permanent infrastructure and improvements cannot be made in slums before they are notified, although I could not find a legal provision that barred public engineering expenditures in slums if they are not notified. However, it would seem as if the notification of a slum brings it administratively under the purview of the municipality, whereas nonnotified slums are not.

The notification process is time-consuming, and it involves technical, administrative and political layers; as a result of which there is usually a queue of 'non-notified slums' that have been identified as slums but have not as yet completed the process of notification. In practice, my colleagues and I usually found small municipal investments, such as in community taps and drainage even in non-notified slums, however, these were usually explained away by officials as 'councilor fund projects' and of a lower order of magnitude than systematic area improvement projects. For a ward councilor, having slums in his or her ward notified is a high priority-and it sometimes slows down the notification process as officials develop a 'balanced' list that covers slums distributed across the city and in as many municipal wards as possible.

The notification process is distinct from, but not entirely unrelated to, the issue of property and tenure claims. Notification could pave the way for municipal infrastructure spending, which in turn could perhaps signal some intent on the part of the municipality to let the slum remain on the site it occupies. However, residents need to build up their property claims in parallel.

Property claims are built up in parallel with documentation that establishes evidence of the household's occupying a site over a period of time. For slums that occupy public land, documentary evidence of site occupation can make a household eligible for a 'patta,' which is a type of temporary property right granted by the state government in slums under a special state law [20]. Pattas are the closest that slum residents can come to ratification of their property claim under applicable law in Madhya Pradesh. The status of patta is awarded on the basis of a survey by the state government (which is the residual owner of all public land in the state). Eligibility is determined on the basis of official identity papers that show residence at the site for a minimum of three years. Testimonies of neighbours are also sometimes considered in lieu of documentary evidence. However, a patta granted under this law can be cancelled at any time by the state government, with a somewhat uncertain right to compensation or alternative accommodation. Nevertheless, this form of tenure is considered heritable and of some value to those who manage to secure it.

At the time of award of patta, the municipality and the state planning agencies are asked for a 'no objection' certificate, which is thought of as a way to rule out patta grants in areas of glaring legal or practical problems. Slums that are on private land, or on land owned by government institutions (such as the railways, the military and public sector companies), are not considered eligible for grant of patta, perhaps for the reason that the 'no objection' certificate would not be forthcoming from the agencies that own the land. Slums on private land (in illegal occupation) may also not be considered for this reason. In theory, slums that are on sites that are unsafe for habitation are also not to be granted patta, however, there seems to be many exceptions to this rule.

There is also another category of slum-like informal settlement, called the "illegal colony" built on farmlands that are sub-divided, sold and bought without planning permission under land revenue, planning and municipal law [21-23]. Illegal colonies also serve low-income housing markets, and could be slum-like in many ways, although legally and administratively they are treated as a separate category. Madhya Pradesh law prohibits registration of sales in illegal colonies, perhaps as a disincentive to potential illegal developers, but this means that 'owners' in these settlements have no documentary evidence of their title. Illegal colonies need a specific type of municipal 'no objection certificate' in order to be considered eligible for services [23], which in turn requires residents to organize themselves to jointly apply and lobby the administration for this certificate. 
Another type of documentation, related to tenure, that slum households have to navigate is the 'property tax registration.' Property tax is generally thought of as a form of municipal revenue, but, in fact, the property tax levy in Madhya Pradesh slums is nominal. The levy of property tax is calculated based on 'rentable value,' but it is considered to be zero in areas designated by the corporation to be slums and low-income settlements. Houses with zero tax levy are only required to pay a small annual sanitation cess). In formal law, property tax registration is considered unrelated to title: by municipal law, owners or 'occupiers' are permitted to apply, and a tax registration is not considered a document of title. However, in practice, it is recognized by the municipality as a way of establishing a connection between the applicant and the property in lieu of regular ownership documents.

The application process for municipal property tax registration requires the applicant's personal government-issued identity documentation and evidence of ownership or occupation of the property, which could include electricity bills or patta documentation. A municipal official told me that if an applicant is unable to provide any evidence document for his occupation of the property, it is still possible for the municipality to establish his status by making a site visit and recording statements of neighbours.

\subsection{Drinking Water Rationality in Legal and Technical Terms}

The municipal law of Madhya Pradesh lists water supply as a function of the corporation, stating that "The Corporation shall make adequate provision, by any means or measures which it may lawfully use or take, for each of the following matters (... )" which includes "the management and maintenance of all municipal water works and construction and maintenance of new work and means for providing a sufficient supply of suitable water for public and private purposes" [23]. In the same section, however, it is also stated that "No suit for damages or for specific performance shall be maintainable against the Corporation or any officer or Councillor thereof, on the ground that any of the duties specified in sub-section(1) have not been performed" [23].

By this law, the municipality has a mandate to provide drinking water in areas under its jurisdiction, and all the power and authority necessary to undertake this mandate; however, it does not cast an obligation to make adequate provision for water and sanitation services to all houses within its jurisdiction. This is, of course, the exact opposite of how this provision was interpreted by the courts in some of the other cases relating to municipal provisioning, where it was held that local authorities and state governments had a duty to make provision for drinking water, and that the lack of funds and resources did not absolve them of their responsibilities [24,25].

Nevertheless, in the municipality's own understanding of its legal obligation, water supply and sanitation services, and household-level formal services (that is, in-house piped water connections), are provided only if infrastructure and resources are available, and certain other legal conditions are satisfied, and if it is 'technically feasible' to do so. The others, who do not meet technical or legal conditions, may still be supplied with municipal water, but in ways that are not as secure or reliable.

In order to obtain an in-house water connection, the owner-occupant of the house is required to make an application to the municipality, in prescribed format and with supporting documentation. The municipality levies a connection charge for new accounts, and bills a monthly charge to user households. There are concessional connection charges and monthly charges applicable for the low-income households that are updated from time to time. These charges are nominal for slum households, and are unlikely to be the principal reason why far fewer of them have house connections as compared to those in non-slum areas. There is a special category of water rates for a low-diameter connection for 'economically weaker sections' and slums, which provides less water and is billed at a lower rate, and also has a lower upfront connection charge. This could be as low as a monthly charge of Rs. 30 (USD 0.50), as compared to a regular monthly tariff of Rs. 180 (USD 3.00) for regular domestic consumers. As water is supplied only for a few hours every day, the larger diameter regular connection allows for more consumption. 
A successful application from a slum household would require the following three pre-requisites: (1) the household should be able to provide supporting documentation, (2) there should be no specific legal prohibition in a particular area, such as if it is on railway or military land, in an illegal colony that does not have a no-objection certificate, or a slum that is not notified and (3) that it should be 'technically feasible' to serve the area, and that it should be within reach of existing municipal pipelines. The households themselves can do little to alter any legal prohibitions applicable to them, and they have limited influence on the technical feasibility question. But they could proactively address the first requirement by lobbying the local administration to bring about slum notification and to improve their household-level documentary status.

It is, however, not always clear what supporting documentation will be considered adequate. In my conversations with municipal officials, I have been told multiple versions of this. There are differing views on whether or not patta documents and property tax registration are essential. Municipal officials have sometimes told me that long-standing residents in areas that are ineligible for patta (such as on certain types of no-man's land) can be considered equivalent to leasehold owners-a view which is unlikely to stand legal scrutiny, but is perhaps adequate for municipal approval. I can only surmise from these varying accounts that, one, political sponsorship helps an applicant's case, and two, that documents are considered in combination, and should add up to a satisfactory statement of the applicant's residential status.

In addition, applicants are asked to provide a plumbing drawing prepared by a licensed plumber, and a statement of endorsement from the local ward councillor. Following submission of the application and documents, the municipal engineer makes a site visit report to check if the house location is within reasonable distance from the main line and whether it is technically feasible to extend a house connection from the main line. This site report (the 'technical feasibility assessment'), along with application documents, is submitted to a zonal executive committee for administrative sanction.

Slums might fail the technical feasibility assessment for the reason that they are built on marginal and inaccessible lands, on rocky, hilly slopes or in far flung areas that are not served by existing municipal networks. These would appear, on the face of it, to be legitimate engineering-related grounds for not being able to sanction house connections. However, in technical feasibility, one must therefore account for disciplinary and training bias. In many conversations with municipal engineers on this point, I learned of the difficulty of planning for and laying pipelines and infrastructure in narrow, congested and twisty layouts. In my consulting assignment in Madhya Pradesh, I observed that it was possible to do this with specialized training and method. The municipal engineers I spoke to, however, had not received such training, except as one-off short-term inputs from programmes such as the one I was working in, even though the same narrow, congested and twisty layouts were part of the everyday reality of the cities they worked in. I also observed (a point confirmed by colleagues in the municipality and in my programme) that, in reality, municipal water supply systems are severely compromised on many engineering parameters by poor design, investment and maintenance. This is not just on account of the slums, but everywhere in the city. Therefore, while it appears as if the decision of technical feasibility is based on engineering conventions, these conventions are deployed sometimes and ignored at other times. Technical feasibility is also not a permanent state, but one that can be altered with targeted investments once an administrative decision to serve an area is taken.

The main question for public officials-at least in terms of procedure-seems to be to ensure that there is enough documentary basis in order for them to sign off on it. There is also an implicit concern of public officials-often stated in one-to-one discussions but rarely in writing - that, if the living conditions in slums are made too comfortable, will it not lead to a proliferation of more slums? Officials who approve expenditure in slums are also perhaps driven by the worry that they should not be seen to be as facilitating land capture or serving interest groups. The maze of documentation, including surveys, 
assessments, government identity papers and no-objection certificates provide ratifications of the legal status of slums, and perhaps some form of legitimacy and 'cover' for the decision-making officials.

\section{Conclusions}

My paper explores the seeming disjuncture between the socio-economic rights discourse of the courts and the everyday realities of local law and practice. There is not much difference in the end in what these two options offer for people. The local route is less risky in terms of a threat of eviction, but as unlikely to provide an outcome if the goal is to have a secure and exclusive house connection. Improvements in the quality, reliability and nearness of community taps seems like a more realistic goal, and one that can be achieved by building up official recognition of the slum and tenurial claims of its residents.

Poor people's lower claims on city water services are, however, not likely to be the outcome of their lesser capacity to pay for services. One of the key concerns about water privatization and 'neoliberal' reform of the state, all over the world, is that an increase in commercial orientation of water utilities will lead to higher tariffs, and increased inequalities and exclusion of those who cannot pay these tariffs. This threat has been largely unrealized in India, at least insofar as urban water supply is concerned. Publicprivate partnerships (PPPs) in urban drinking water are, at least for now, few and far between in India: according to a study commissioned by the World Bank, only 15 PPP projects in urban water supply were awarded between 2006-2011, all with low commercial risk for the private parties, and, of these, only 8 achieved financial closure [26]. Indian government officials, national and state, and in the city municipalities, all profess interest in institutional reforms to reorganize water supply operations on commercial lines. However, in fact, the municipalities and other service providing agencies have not reached very far in implementing this vision. In Mumbai, the disconnection policy perhaps resulted in large number of consumers paying quite a lot for illegal connections, while at the same time shrinking the revenue base of the municipality. The policies I looked at in Madhya Pradesh are not quite so counterproductive, but seem not to be driven by a revenue motive.

The lack of a decent level of water access in slums is also not entirely a weak state problem. Services are poor all over Indian cities, but they, specifically, are worse in certain areas than in others. The real issue, and the one for rights jurisprudence to confront, is about contested claims over land. Formal markets of land and housing give primacy to certain types of capital and interest groups over others, and the insistence on certain types of legalism over others aligns well with these interests. Looking at it from this perspective, we can see why policies in Mumbai (India's financial capital, with some of the highest real estate values in the world) are so different from those in smaller provincial cities in Madhya Pradesh. In both places, however, the municipal arena, chaotic and low profile as it is, provides some space to negotiate these interests in ways that are not possible in the court. This space is precarious, as the municipalities are by no means insulated from land contestations, although their close-to-the-ground location makes it difficult for them to entirely ignore people's voices.

In the end, what should we make of these case studies in the discourse of rights? They underscore the importance of working on developing a better and more holistic understanding of the right to water. The recognition of rights should not be accompanied by the threat of evictions, but rather by the recognition of multiple and social purposes of urban land. My case studies also highlight the need for rights to become local, and to think of ways to make the local interface of poor people and the state more empowering. In this, we need to engage with the legal framework, and rule and policy for water provisioning to develop better footholds for people in excluded settlements to make their claims. We also need to be able to listen to people in excluded settlements to understand what difficulties they face and how the discourse of rights can be deployed and reshaped to address these difficulties. 
Funding: This research was supported by the following project: "Elevating water rights to human rights: Has it strengthened marginalized people's claim for water?", Research Council of Norway, Project No. 263096.

Acknowledgments: In thinking about this paper, I benefited enormously from many conversations with Aditya Bhol and Shamindra Nath Roy. They also helped me with analysis of national survey data.

Conflicts of Interest: The author declares no conflict of interest.

\section{References}

1. Report No. 561(69/0.21) on Urban Slums in India from the National Sample Survey 69th Round in 2012; National Sample Survey Organisation, Government of India: New Delhi, India, 2012.

2. $\quad$ Singh, V. Walking with Water; Hyderabad Urban Labs: Hyderabad, India, 2017.

3. Björkman, L. Of Pipes and Slums: Understanding Mumbai's Proposed New Water Rules for Residents of "Illegal Structures". Available online: https: / casi.sas.upenn.edu/iit/lisabjorkman (accessed on 12 September 2020).

4. Anand, N. Municipal Disconnect: On Abject Water and Its Urban Infrastructures. Ethnography 2012, 13, 487-509. [CrossRef]

5. Chatterjee, P. The Politics of the Governed: Reflections on Popular Politics in Most of the World; Leonard Hastings Schoff Memorial Lectures; Columbia University Press: New York, NY, USA, 2004; ISBN 978-0-231-13062-2.

6. Björkman, L. Pipe Politics, Contested Waters: Embedded Infrastructures of Millennial Mumbai; Duke University Press: Durham, UK, 2015; ISBN 978-0-8223-5950-0.

7. Auerbach, A.M. Demanding Development: The Politics of Public Goods Provision in India's Urban Slums; Cambridge University Press: Cambridge, UK, 2020.

8. McFarlane, C.; Desai, R. Sites of Entitlement: Claim, Negotiation and Struggle in Mumbai. Environ. Urban. 2015, 27, 441-454. [CrossRef]

9. Pani Haq Samiti and Ors. V. Brihan Mumbai Municipal Corporation and Ors. Order Dated 15 Dec 2014 in Public Interest LItigation No. 10 of 2012 in the High Court of Bombay. Available online: https://bombayhighcourt.nic.in/index.php (accessed on 16 November 2021).

10. Husain, Z. Water, Their Fundamental Right, Is All They Want. Hindu. 2018. Available online: https://www.thehindu.com/news/ cities / mumbai/water-their-fundamental-right-is-all-they-want/article25713428.ece (accessed on 16 November 2021).

11. Water Works_-Welcome to Municipal Corporation of Greater Mumbai, India. Available online: https://portal.mcgm.gov.in/irj/portal/ anonymous?NavigationTarget=navurl:/ / 06f20212cc919da73149e1e9ef479e42\&guest_user=english (accessed on 7 February 2021).

12. Samiti, P.H.; Centre for Promoting Democracy. Moving Toward Universal Water E Sanitation Access: A Ground Assessment of WASH Realities of Mumbai's Informal Settlements in COVID-19 Times; Vikas Adhyayan Kendra: Mumbai, India, 2020.

13. Vision Mumbai: Transforming Mumbai into a World Class City a Summary of Recommendations; Bombay First I McKinsey \& Co.: New Delhi, India, 2003.

14. Final Report: Independent Evaluation of the Community Led Infrastructure Finance Facility (CLIFF) for Cities Alliance; GHK International: London, UK, 2006.

15. Gandy, M. Landscapes of Disaster: Water, Modernity, and Urban Fragmentation in Mumbai. Environ. Plan. A 2008, 40, 108-130. [CrossRef]

16. Lipsky, M. Street-Level Bureaucracy: Dilemmas of the Individual in Public Services, 30th ed.; Russell Sage Foundation: New York, NY, USA, 2010; ISBN 978-0-87154-544-2.

17. M.P. Gandi Basti Kshetra (Sudhar Tatha Nirmulan) Adhiniyam, 1976. (Translated as Madhya Pradesh Slum Areas (Improvement and Clearance) Act, 1976). Available online: http:/ /www.bareactslive.com/MP/MP278.HTM (accessed on 16 November 2021).

18. Durand-Lasserve, A.; Fernandes, E.; Payne, G.; Smolka, M. Secure Tenure for the Urban Poor. CIVIS Learn. Cities $2002,3,8$.

19. Payne, G. Urban Land Tenure Policy Options: Titles or Rights? Habitat Int. 2001, 25, 415-429. [CrossRef]

20. M.P. Nagariya Kshetron Ke Bhumihin Vyakti (Pattadhruti Adhikaron Ka Pradan Kiya Jana) Adhiniyam, 1984. (Translated as Madhya Pradesh Landless Persons in Urban Areas (Grant of Patta Rights) Act, 1984). Available online: http:/ / www.bareactslive. com/MP/MP535.HTM (accessed on 16 November 2021).

21. Madhya Pradesh Land Revenue Code. 1959. Available online: http://www.bareactslive.com/MP/mp381.htm (accessed on 16 November 2021).

22. The M.P. Nagar Tatha Gram Nivesh Adhiniyam, 1973. (Translated as Madhya Pradesh Town and Country Planning Act, 1976). Available online: http:/ / www.bareactslive.com/MP/MP539.HTM (accessed on 16 November 2021).

23. Madhya Pradesh Municipal Corporation Act. 1956. Available online: http://www.janaagraha.org/asics/report/MadhyaPradesh-Municipal-Corporation-Act-1956.pdf (accessed on 16 November 2021).

24. Gautam Uzir vs. Gauhati Municipal Corporation. Order dated 10 Aug 1999 in Civil Rule (PIL) No. 10 of 1999, 1999 (3)GLT 110. Available online: www.ielrc.org/content/e9918.pdf (accessed on 16 November 2021).

25. S.K. Garg vs. State of U.P. And Ors. on 28 May, 1998. (1998) 2 UPLBEC 1211. Available online: https://indiankanoon.org/doc/8985 22/ (accessed on 16 November 2021).

26. Running Water in India's Cities: A Review of Five Recent Public-Private Partnership Initiatives; Flagship Report; International Bank for Reconstruction and Development/The World Bank: Washington, DC, USA, 2014. 